\title{
Preparing for the Worst Crisis Scenario on the Flag Carrier Garuda Indonesia in Digital Era
}

\author{
http://dx.doi.org/10.25008/jkiski.v6i1.494
}

\author{
Aqida Nuril Salma ${ }^{1^{*}}$ \\ ${ }^{1}$ School of Communication and Business, Telkom University \\ Jl. Terusan Buah Batu, Sukapura, Kec. Dayeuhkolot, Bandung 40257 - Indonesia \\ *Corresponding author: aqidasalma@telkomuniversity.ac.id
}

Submitted: February 21, 2021, Revised: March 26, 2021, Accepted: May 02, 2021

Accredited by Kemristekdikti No. 28/E/KPT/2019

\begin{abstract}
Life in the digital era runs instant and fast-paced. The development of science and technology, especially the Internet and social media has a very strong influence. Not only does it affect the daily activities of people's lives, but also the activities of the professional world, especially in crisis communication that is considered more complex, and even raises new possibilities in which each company will be more vulnerable to crisis with a greater impact than ever. Thus, preparing for the worst possible scenario will help a crisis situation go as smoothly as possible. In consequence, organizations today are required to have a structured and internet-based crisis communication plan and policy as an effort to respond to these developments. This research paper presents an exploratory study conducted to understand how the practitioners prepare for the worst scenario and the strategy of handling it, and how the planning is influential to the success of crisis communication. An indepth interview was conducted to senior corporate communication executives and crisis manager from High Reliability Organization (HRO). This paper concludes by suggesting and drawing up guidelines for practitioners to structuring an effective crisis communication plan as well as directions for future research in this domain for researchers to take up.
\end{abstract}

Keywords: Crisis communication; crisis management; crisis plan; crisis preparedness; digital public relations

\section{Introduction}

In this digital era, companies may have to go through crisis more often than before. Therefore, much of the work researching into the new phenomenon in the area of crisis communication and public relations in general have begun to surface on how organizations could survive in this new wave. Entering the world of digital disruption, crisis communications, both theoretically and in practice, have been much renewed to welcome the emergence of the Internet as a new media. The dynamic of the digital media platforms offered at once granted organizations another avenue of connection with stakeholders and public, but at the same time, the high interactivity of digital media may cause negative consequences, such as it could be used to escalate and trigger the new crisis. But in fact, the internet is not the only medium that brings change to crisis communications. From the "Declaration of Principles" that belongs to Ivy Lee, until the emergence of mass media such as radio and television has brought a broader perspective on crisis communications.

Indeed, information technology has dramatically changed the way public relations practitioners distribute information, interact with key publics, deal with crises, and manage issues (Hallahan, 2004). Particularly in crisis communications activities, it is perceived to be increasingly complex, as it also raises new possibilities where each company will be more vulnerable to a crisis with greater impact than ever. It has been estimated that one out of four crises today are related to the internet (Herbst, 2001), and 
in the last ten years, incidents of online crises reaching mainstream media have seen a ten-fold increase (Owyang et al., 2011). Supported by research results which show that the Internet can be an effective crisis communication new tools, but it can also serve as platforms where crises can be triggered (González-Herrero \& Smith, 2008; Pang et al, 2014). In other words, it can be said that the internet has in turn triggered more and more new threats and challenges which are truly unavoidable for every Public Relations practitioner in today's digital era.

Even before the advancement of technology and digital media, crises are often examined as unexpected events that have potentially negative consequences for organization (Barton, 1993). In a public relations context, however, crises can be more precisely defined as the state of uncertainty resulting from a triggering event that disrupts an organization's routine activities (Ho \& Hallahan, 2004). With its uncertainty and complexity characteristic, preparing for future crisis scenario is necessary for every organization which wants to be successful in their crisis management. As such, preparedness is an important element of anticipating a crisis that involves mentally rehearsing scenarios and equipping the organization with systems and procedures so that responses are appropriate, sufficient, and timely (Hill, 2002).

Not to mention digital crisis automatically demands more for the availability of crisis planning. Indeed, if we look at the social media characteristics which provide the possibility for a crisis to spread and develop in a new way, and affect the overall stages of crisis communication, be it pre-crisis stage, during crisis or post-crisis. Social media is the collective term of Web 2.0 technology which can be described by some characteristics such as participation, openness, conversation, and connectedness (Coombs, 2011). In the context of crisis communication, the impacts of social media can be their speed, message control, interactivity, message originality, boundaries, transparency and the new media for crisis and its trigger. The point is that with the emergence of the Internet there will be another and new potential triggers of crisis, thus, companies today must regularly monitor the digital world to find threats that will potentially harm the company's reputation.

To counter crisis in this digital era, having crisis communication planning is the right thing. According to research result, many business leaders agree that all companies experience digital crisis but do not know how to apply any actions to overcome it (Valackiene, 2010). It has been encountered by many big companies that suffered huge losses due to the crisis that occurred originally from the Internet and then became the subject of discussion and publication that spread widely in a short time and become viral. One example is a big company United Airlines that had experienced a crisis after one passenger expressed his dissatisfaction with the airline through YouTube. Due to the lack of awareness of the importance of updating their crisis communication strategy to be internet-based, United Airlines was considered a total failure in managing the crisis (Chi, 2017). The incident is said to be one of the worst in the history of Public Relations practice, and some even call it as a Public Relations Disaster. Therefore, it is important to conduct further study related to crisis communication in the digital age so that no other United Airlines are expected to be out there.

In the context of Indonesia, there is a company that is known to be serious in handling future crisis scenario through crisis planning and preparedness, namely PT. Garuda Indonesia (Persero) Tbk. As an airline company, Garuda Indonesia is aware of their position as a High Reliability Organization, and how they are very vulnerable to crisis. Looking at that condition, accordingly, they draft a written policy related to crisis management and communication that has been decided and approved by all levels of company's management, called the Emergency Response Plan, hereinafter abbreviated as ERP. The policy was created as the company's efforts in dealing with worst events that they found it hard to predict (unpredictable event) in the future. The crisis situation faced by airlines is not an ordinary crisis situation (Ray, 1999), it even tends to be an object of interest from all people around the world (Grundy and Moxon, 2013). By that, the management team hopes that ERP will reduce its impact resulting from the crisis to be faced by the company.

Changes that occur in crisis communication, both theoritically and in practice, certainly cannot be avoided, especially when the media is the only channel to evolve. For academics, it will be a new homework to study, while for practitioners it is the right time to devise a new strategy that is aligned with the existing technology development. Over recent years, increasing academic interests have been seen in relation to how digital media has changed crisis communication and management activities. Hill and White (2000), for instance, studied how the internet could fit into the organization's communications mix. White and

Raman (1999) studied how corporate communications could use the internet to further the organization's goals through careful web 
planning. Perry et al (2003) explored how organizations could holistically integrate the internet into their crisis communications approach.

Thus, far, it appears that much of previous crisis communication literature have placed digital media and technology as their research subject, but they rarely developed any systematic methods and planning for digital crisis communication handling strategy. They only focus on how the public relations practitioners use digital media to handle crisis without any specific and technical methods. Although, research suggests that organizations are often unprepared for the information gathering and dissemination tasks required for the effective handling of a crisis (Coombs, 1999). As such, this research will specifically address prominent question on how corporate should prepare for future crisis in the age of digital disruption and uncertainty? The prime objective of this research is to suggest and draws up guidelines for practitioners to structure an effective crisis communication and management plan, as well as to highlight the importance of adopting crisis communication planning in digital era. It is hoped that public relations and corporate communications practitioners would find this research useful as they integrate it into their crisis management and communication planning.

\section{Theoretical Framework}

There are, however, always two sides of the coin, in which whether the internet can be a new facilitator for a crisis or otherwise it is a trigger of a new crisis. This study presents arguments about both sides of an issue of an emerging and underexplored side of new media for crisis communication and how it is used as an accessory in escalating as well as preventing crises. The Internet provides any organization, large or small, with a direct link to relevant publics and it can also serve as a link to other valuable Websites. In other words, the information gathered from the Internet can help organizations adjust policies and actions before a crisis occurs. As Grunig (2009) has argued that the presence of technology in the form of the internet can also help PR in preparing communication programs, one of which is called as issue and crisis preparedness anticipation. Today, PR practitioners in the company can easily monitor public opinion spread around forums or social media related to a potential crisis to help the company's management team to further take steps and decisions to resolve the crisis before it comes to the surface. The literature on crisis management in general also acknowledges the importance of the exact circumstances for an organization's way of planning proactively and of handling crises
(Olofsson, 2011; Crichton, et al., 2009; Mayer, et al., 2008; Toft and Reynolds, 2005).

Although crisis communications have received extensive attention over the past two decades, comparatively little research exists about the actual level of crisis preparedness within public relations (Cloudman and Hallahan, 2006). Only about $40-50 \%$ of U.S. companies have written crisis plans (Kiger, 2001; Penrose, 2000), while communication has received little attention in efforts to develop measures of organization-wide crisis preparedness (Kim, 2004; Pauchant \& Mitroff, 1992). As crises are often defined as an unexpected event that has potentially negative consequences for organization (Barton, 1993), and the state of uncertainty resulting from a triggering event that disrupts an organization's routine activities (Ho \& Hallahan, 2004). Hence, it is important to emphasize how important is crisis preparedness as a part of successful crisis communication and management, especially in this digital era. Crisis managers need to prepare for the crises of the future (Boin \& Lagadec, 2000).

Preparedness can be defined as an important element of anticipating a crisis that involves mentally rehearsing scenarios and equipping the organization with systems and procedures so that responses are appropriate, sufficient, and timely (Hill, 2002). There is no standard definition of crisis communication preparedness in the literature, but Gonzalez-Herrero and Smith (2008) suggest a four-stage model for crisis management in the virtual world which I consider relevant to crisis preparedness that this study has discussed. The four-stage model shows a correspondence of crises with the biological model in which an organism passes sequentially through phases of birth, growth, maturity, and decline (death) (Gonzalez-Herrero and Smith, 2008). The four phases described in this crisis management model includes issues management, planning-prevention, the crisis, and the post-crisis. Both issues of management and planning-prevention stages will be used to analyze the research results of this study in view of its close relevance.

\section{Material and Methodology}

Considering that the nature of this study is mainly exploratory and drawing insights of DiNardo's (2002) study on how organizations used the internet to manage crises, this study similarly uses the qualitative method of analysis. Qualitative research, may provide detailed views and perspectives of the extent to how and in what ways the digital media can be used for an effective crisis communication and how it highlights the importance of preparing for the worst scenario by 
adopting a structured and internet-based crisis communication planning. Qualitative research is an effective methodology for representing real life in natural occurrences and achieving richness and depth (Denzin \& Lincoln, 2003).

Qualitative data was largely be gathered through in-depth interviews with a number of informants and direct observation in selected research locations in Indonesia. To obtain in-depth information, face-to-face interview was conducted directly to a number of selected informants that were fully involved in the preparation of a crisis communication strategy whether before the crisis, during the crisis and after the crisis, in the Corporate Communications and Corporate Quality, Safety \& Environment Management.

The interviewees for this research are: Emergency Response Plan Manager, Indra Nur Arfianto; Senior Manager of Public Relations, Sheila Indira Maharshi; Vice President of Corporate Communications, Ikhsan Rosan. Moreover, this research specifically chooses Garuda Indonesia with a special reason, since it belongs to the High Reliability Organization (HRO), which has characteristics as an organization operating in a very complex environment as well as very vulnerable to crisis, thus, the HRO organizations in general will be obliged to have a qualified crisis management and communication formula.

\section{Result and Discussion}

This section presents the result and discussion divided into two parts. The first part discusses planning and prevention and the second part is about issue management. Based upon a literature review of Cloudman and Hallahan (2006) and Gonzelez-Herrero and Smith (2008), this study focused on two key activities in which organizations might engage and thus serve as practical indicators of crisis preparedness. The two phases described in this crisis communication preparedness model are planning-prevention and issues management.

The Planning-prevention phase focused on prevention where the organization should brace itself for the possible crisis and plan for other potential scenarios. This requires not only monitoring the environment in search of warning signs but also preparing for a possible negative impact of an issue. In other words, at this stage, the organization should ask itself: What can we proactively do in advance of a possible crisis? How can we use Internet-based technologies to help us minimize the potential negative consequences of a crisis? During the planning-prevention phase, the company should:

\section{Presence of a written plan}

Based on the observation, Garuda Indonesia has had written crisis communication plan called Emergency Response Plan. Not every company is serious sbout handling their crisis, and some even opine that making crisis planning is boring. Whereas, plans provide a critical blueprint for training, pre-determine best practices, and can save precious response time (Caywood \& Stocker, 1993; Fearn-Banks, 2002). The presence of written plan will help deal with the crisis faster so as to avoid more severe damage. Meanwhile, the lack of planning, according to Mitroff and Pearson (1993), Director of the University of Southern California's Center for Crisis Management can increase a company's potential for crisis. Research found that even large companies cannot survive from crisis if they do not have a good crisis management and communication plan (Penrose, 2000). As argued by ERP Manager below:

\begin{abstract}
"So why do we need this ERP? so that we move quickly. Try to imagine, for example, that we have an event that causes people to get hurt, if we don't hurry up and take care the injury, then what will happen? People who are supposed to survive can actually die right? People who shouldn't be injured will be injured, right? That is one of important reason why ERP is needed."
\end{abstract}

Based on observations and archival search made, it is known that the ERP began to be compiled in 2005 and was endorsed by the company's management in 2006. ERP itself was first applied to a plane crash crisis situation in Yogyakarta that happened to Garuda Indonesia. As a result, Garuda ERP for the first time received an award from IPRA (International Public Relations Association) in 2007 and was also chosen as a benchmark for other organizations in handling crisis management.

There are several main aspects that must be prepared when developing a crisis communication policy. Based on observations that have been made, this includes determining indicators of a crisis or a potential crisis, followed by forming a crisis communication team. Dilenschneider et al. (1985) recommends that companies should develop a catalog of potential crises. Carney (1993) also shows that companies must conduct audits to evaluate areas where their company could experience a loss or experience something that endangers the existence of the company. From there the company can hone its sense of crisis well. In this case, Garuda Indonesia has identified at least 9 areas which have the huge potential to become a crisis, and has become the main focus in 
the discussion of Emergency Response Plan (ERP). Figure 1 below shows example of 9 crisis potential areas identified by crisis managers at Garuda Indonesia. These 9 areas have different crisis management strategies and each of them has been written one by one in the book of crisis plan, called Emergency Response Plan.

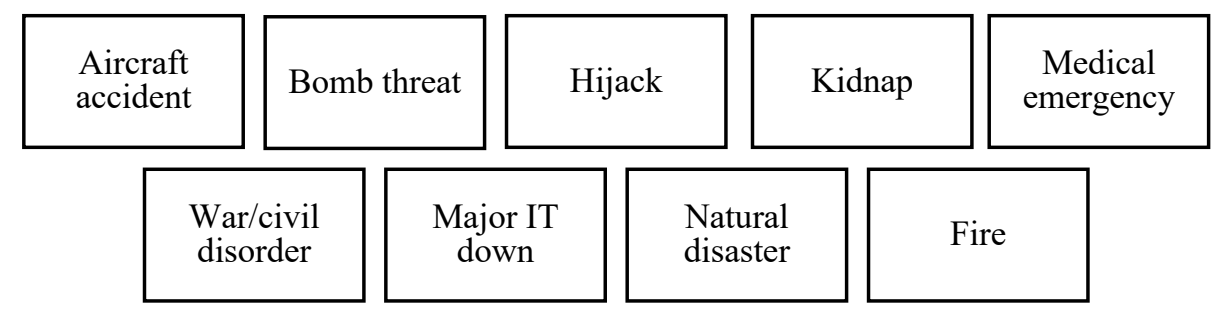

Figure 1. Example of Crisis Potential Areas (Source: Observation and archival search)

Furthermore, effective plans must be updated periodically and made accessible to all individuals who might be involved in a crisis response (Caponigro, 2000; Penrose, 2000). Garuda Indonesia is known to have recognized that digital media trend is one aspect that needs special attention. Therefore, they also indirectly agreed on the importance of updating their ERP following digital developments. The manual update is also known to be one of the means of 'updating ERP that has become a routine agenda that must be done either by corporate communication or the ERP division itself. As mentioned by Indra:

"Our ERP is regularly updated and it is mandatory once every 2 years, if this year the schedule is in April then we will do another update. But still, on the other hand, we monitor, we evaluate continuously any developments outside that will affect ERP. And yes, one of them is the development of social media, and the impact of the internet is also often discussed at meetings."

\section{Tactical Preparedness}

A written plan must be supported by tactical preparation - an aspect largely overlooked in crisis research (Stacks, 2004). Key tactical elements include the appointment of a crisis team to anticipate contingencies and then take charge during a crisis (Littlejohn, 1983). Indeed, in addition to a planning and policy that requires clear goals and mission, it is also requires a good teamwork with specific responsibilities related to handling crisis situations. Garuda formed a division that specifically handles ERP included in the Corporate Quality, Safety, and Environment Management division. The division also outlined the importance of the company to make a structured plan to deal with future and current unexpected situations.

In addition, there are special teams that are only formed during crises so as not to disrupt the work of teams that still handle normal business operations. Quoting from Coombs (2007) where a crisis team consists of a cross-functional group of people in an organization that has been appointed to handle a crisis. There are at least five main teams that should be involved, which are: Media Information Center (MIC), Family Assistance Center (FAC), Passenger Inquiry Center (PIC), Site Control Center (SCC), and Departmental Actions (Figure 2). 


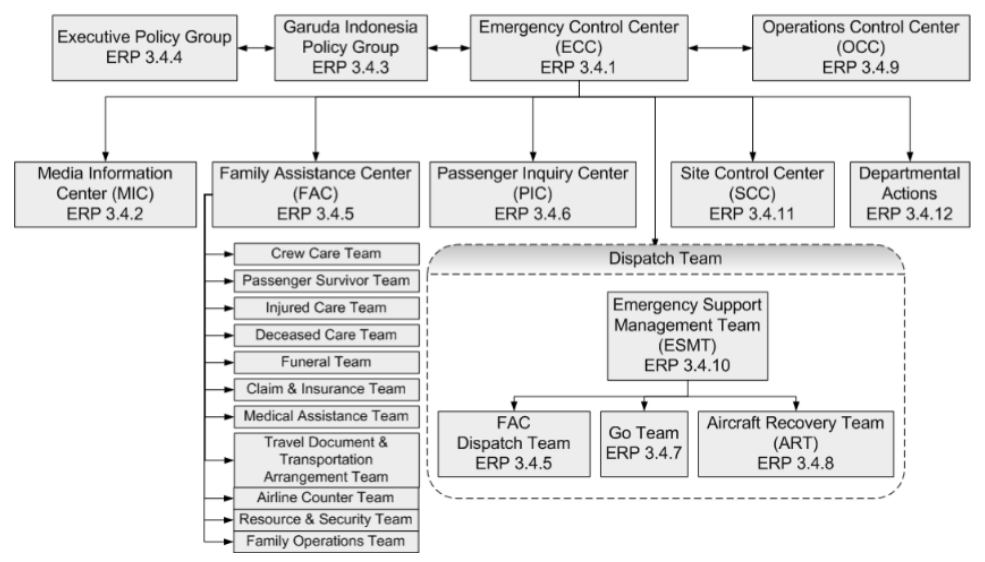

Figure 2. Example of Crisis Team Based on ERP Document (Source: Observation and archival search)

Of the many units above, the most relevant to the study of crisis communication is, of course, the Media Information Center (MIC). Garuda has been very aware of the importance of communication and transparency in times of crisis and therefore, MIC is placed in the core team or the main unit in ERP. Based on the study of ERP documents that have been carried out, MIC has had the role and responsibility to provide information to the public and the media about business interruptions or other crisis situations that will affect the company's image and reputation, handle all questions from the media crew, provide press releases for external side such as media and internal side such as employees, coordinate conferences with the media, and also monitor media coverage, while at the same time being the coordinator and supervisor of every communication activities.

In addition, organizations must also prepare for crises through the creation of a contingency web site and related Internet tools (Middleberg, 2001). In this regard, Garuda Indonesia has prepared several important tools besides social media specifically for the crisis phase, which they argued as the most important as they called it as dark website.

The dark site was created by Garuda as an effort to respond to digital developments that demanded every company especially those which are engaged in the aviation industry to have a major internet-based media that is very useful to face crisis situations. Dark site is expected to be the main media for the public and related stakeholder to find information related to the crisis. Although, so far, this dark site has never been activated and hopefully never will be. The respondent, ERP Manager has explained in more detail about their crisis website:

"Of course, we must follow every development that exists. If in the context of the

\begin{abstract}
development of digital media, one of our new products is the dark site. Dark site is one of the results of ERP updates that follow digital developments. The making of this dark site involves people from corporate communication and IT units. And we have also finished our dark site simulation with the related teams."
\end{abstract}

Dark site or often called as crisis-ready website, is a special website created for crisis situations. This website can be used as the main source of credible crisis-related information as it is officially delivered from the company. In addition, the dark site was created with the aim of controlling negative rumors or issues that were questioned at the time of the crisis. Because social media offer alternative sources of news and information, but it could also lead to the spread of inaccurate information, spoofs and "spin-offs" (Ho et al., 2011).

Guiniven (2004) shows example of how dark site could be useful to develop even before it is actually needed. He notes that U.S. dairy associations established a dark site in the wake of the 2001 foot-and-mouth disease outbreak in Europe. He indicates that dark sites date back to at least 1998, when Swiss air Flight 111 crashed off the coast of Nova Scotia, killing all 229 people aboard. Swiss air's dark site was activated within minutes of the tragedy, providing information to its publics and establishing the value of such sites.

\section{Issue Management}

The core of any issues management practice is to identify, track, and manage potentially conflicting issues by influencing their course. The Internet has important implications for the practice of issues management and vigilant monitoring in the age of the Internet is now a critical part of corporate communication (González-Herrero \& Smith, 2008). Effective issue management can be 
in the form of crisis prevention, which is carried out by the ERP manager and crisis communication or MIC team by solving the issue before it develops into a severe crisis. By giving statements related to whether or not the issue is correct or by transferring the issue to a more positive one could cover up the negative issues. As a Public Relations Senior Manager has emphasized:

\begin{abstract}
"Issue management is purely our work as the corporate communication practitioners. For example, when we have a very potential issue related to the company's reputation, then we will issue a confirmation statement right away. In the past, we have the right to answer to the journalists, if there is news that is not appropriate, then we have a right to reply and giving explanation."
\end{abstract}

\section{Media Monitoring}

The core of issue management activity that should be taken at this phase is media monitoring. Crisis preparedness involves media monitoring as systematic environmental scanning and protocols for designating triggering events. Hence, organizations must identify trends or events that might affect them, and then pre-determine what circumstances or conditions would prompt organizations to go into crisis response mode (Campbell, 1999). This especially involves keeping abreast of developments in the print and broadcast media and the Internet. Media monitoring have always become the daily activity of Public Relations and Corporate Communication at HRO, as highlighted by the Senior Manager: "Well for that, we always routinely conduct media monitoring, both print and online media."

As Thomsen (1995), Heath (1997, 1998), and Hearit (1999) in González-Herrero \& Smith (2008) have all indicated how online databases, web pages, and other online resources can be useful when looking for emerging issues and problems, and can help corporations to adjust policies and actions before a crisis occurs. Today, there is a diverse array of monitoring and information services provided online and some of them are free to access, such Google Alerts, Hootsuite, Social Mention, TweetDeck and KeyHole.

\section{Conclusion}

The use of new media in crisis is a doubleedged sword. On the one hand, it plays a pivotal role in online monitoring and dissemination of information in helping an organization to manage crisis. On the other hand, it can also create a new corporate crisis. Therefore, to anticipate the negative ones, we need to take into account the importance of crisis communication planning which Garuda Indonesia has already done through the Emergency Response Plan. In this case, Garuda Indonesia is considered to be part of 'crisis prepared' company despite many criticism regarding on how poor Garuda Indonesia in reacting to the latest crisis. However, in fact, they already brace for the worst scenario by writing and drafting the emergency response plan and only activating that plan when crisis occurs. They also actively monitor media as a part of daily public relations activities.

Finally, this research suggests a new agenda for future researchers to examine the role of big data and artificial intelligence in crisis communication and management field, especially on how to manage big data to predict and brace for possible future crisis. In addition, we believe that it is advisable for future research to use a larger set of interviews which could reveal more research area, or maybe make quantitative approach to draw more insight in this field.

\section{References}

Barton, L. (1993). Crisis in Organizations: Managing and Communicating in the Heat of Chaos. South-Western: Publishing Co.

Boin, A., \& Lagadec, P. (2000), Preparing for the Future: Critical Challenges in Crisis Management. Journal of Contingencies and Crisis Management, 8: 185-191. https://doi.org/10.1111/1468-5973.00138

Campbell, R. (1999). Crisis control. Sydney: Prentice Hall.

Caponigro, J. R. (2000). The crisis counselor: A step-by-step guide to managing a business crisis. Chicago: Contemporary Books.

Carney, A., \& Jorden, A. (1993). Prepare for business-related crises. Public Relations Journal, 49, 34-35.

Caywood, C., \& Stocker, K. P. (1993). The ultimate crisis plan. In J. A. Gottschalk (Ed.), Crisis response. Inside stories on managing image under siege (pp. 409-428). Detroit: Visible Ink.

Cloudman, R., \& Hallahan, K. (2006). Crisis communications preparedness among U.S. organizations: Activities and assessments by public relations practitioners. Public Relations Review, 32 (4), 367-376.

Coombs, W. (1999). Information and Compassion in Crisis Responses: A Test of Their Effects, Journal of Public Relations Research, 11 (2), 125-142.

Coombs, W. T. (2011). Ongoing Crisis Communication: Planning, Managing and 
Responding. 3rd edition. Thousand Oaks: SAGE.

Crichton, M. T., Ramsay, C. G. \& Kelly, T. (2009). Enhancing organizational resilience through emergency planning: Learnings from crosssectoral lessons Journal of Contingencies and Crisis Management, 17(1): 24-37.

Denzin, N, K., \& Lincoln, Y, S. (2009). Handbook Qualitative Research. Yogyakarta: Pustaka Pelajar.

DiNardo, A. M. (2002). The internet as a crisis management tool: a critique of banking sites during Y2K. Public Relations Review, 28 (4), 367-78.

Fearn-Banks, K. (2002). Crisis management: A casebook approach (2nd ed.). Mahwah, NJ: Lawrence Erlbaum Associates.

Gonzalez-Herrerro A. and S. Smith. (2008). Crisis Communications Management on the Web: How Interned-Based Technologies are Changing the Way Public Relations Professionals Handle Business Crises. Journal of Contingencies and Crisis Management, 16 (3), 143-153.

Grundy, M., \& Moxon, R. (2013). "The effectiveness of airline crisis management on brand protection: A case study of British Airways" Journal of Air Transport Management. 28: 55-61.

Grunig, J. (2009). Paradigms of Global Public Relations in an Age of Digitalisation. Prism Journal 6 (2). 1-19.

Guiniven, J.(2004). Crisis-ready websites. Public Relations Tactics, 11(2):p.6.

Hallahan, K. (2004). Protecting an organization's digital public relations assets. Public Relations Review, 30 (3), 255-268.

Herbst, D. (2001). Internet-PR. Berlin: Cornelsen.

Hill, A. (2002). Rapid response. Managing a crisis requires fast reactions. PR Week, (August), 11 (LexisNexis Academic).

Hill, L.H. and White, C. (2000). Public relations practitioners' perceptions of the world wide web as a communication tool. Public Relations Review, 26 (1), 31-51.

Ho, F., \& Hallahan, K. (2004). Post-earthquake crisis communications in Taiwan: An examination of corporate advertising and strategy motives. Journal of Communication Management, 8 (3), 291-306.

Kiger, P. (2001). Lessons from a crisis: How communication kept a company together. Workforce, 80(November (11)), 28-36.

Kim, Y. (2004). How to evaluate an organization's crisis-preparedness. Development and application of an index. Paper presented to
International Communication Association, New York.

Littlejohn, R. F. (1983). Crisis management: A team approach. New York: AMA Publications.

Mayer, B. W., Moss, J. \& Dale, K. C. (2008). Disaster and preparedness: Lessons from hurricane rita. Journal of Contingencies and Crisis Management, 16(1): 14-23.

Middleberg, D. (2001). Winning PR in the wired world. New York: McGraw-Hill.

Mitroff, I., \& Pearson, C. M. (1993). Crisis Management: a diagnostic guide for improving your organization's crisispreparedness. San Francisco, CA.: JosseyBass Publishers.

Olofsson, A. (2011). Organizational Crisis Preparedness in heterogeneous societies: the $\mathrm{OCPh}$ model. Journal of Contingencies and Crisis Management, 19(4) 215-226.

Owyang, J., Jones, A., Tran, C. and Nguyen, A. (2011), Social Business Readiness: How Advanced Companies Prepare Internally, Altimeter Group, available at: www.slideshare.net/jeremiah_owyang/socialreadiness-how-advanced-companies-prepare (accessed November 8, 2011).

Pang, Augustine \& Hassan, Nasrath \& Chong, Aaron. (2014). Negotiating crisis in the social media environment: Evolution of crises online, gaining credibility offline. Corporate Communications: An International Journal. 19. 10.1108/CCIJ-09-2012-0064.

Pauchant, T. C., \& Mitroff, I. I. (1992). Transforming the crisis-prone organization. San Francisco: Jossey-Bass Publishers.

Penrose, J. M. (2000). The role of perception in crisis planning. Public Relations Review, 26 (2), 155-171.

Perry, D., Taylor, M. \& Doerfel, M.L. (2003). Internet-based communication in crisis management. Management Communication Quarterly, 17 (2), 206-32.

Ray, S.J., (1999). Strategic Communication in Crisis Management: Lessons from the Airline Industry. Westport, CT: Quorum Books.

Stacks, D. W. (2004). Crisis management: Toward a multidimensional model of public relations. In R. L. Heath, \& D. P. Millar (Eds.), Responding to crisis: A rhetorical approach to crisis communication. Hillsdale, $\mathrm{NJ}$ : Lawrence Erlbaum Associates.

The British Broadcasting Corporation (BBC). Not so friendly skies: United Airlines' public relations disaster. Retrieved on https://www.bbc.com/news/business39562182. 
Toft, B. \& Reynolds, S. (2005). Learning form disaster: A management approach. Leicester: Perpetuity Press.

Valackiene, A. (2010). Efficient corporate communication: decisions in crisis management. Inzinerine EkonomikaEngineering Economics, 21 (1), 99-110.

White, C. \& Raman, N. (1999). The world wide web as a public relations medium: the use of research, planning, and evaluation in web site development. Public Relations Review, 25 (4), 405-19. 